\title{
Knowledge and Attitudes Toward Epilepsy Among Students of Health Occupations in a University
}

\author{
Bir Üniversitede Öğrenim Gören Sağlık Meslek \\ Öğrencilerinin Epilepsiye Yönelik Bilgi ve Tutumları
}

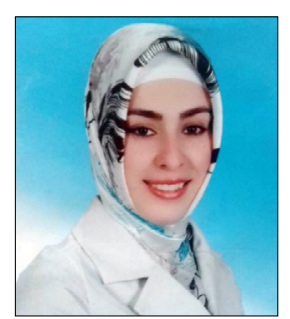

Dr. Kübra YENi

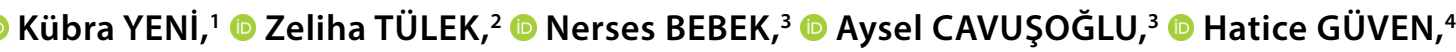

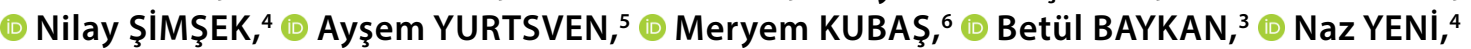

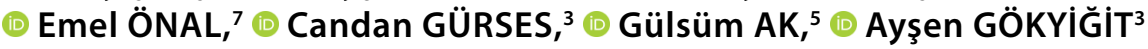

'Department of Medical Nursing, Ondokuz Mayıs University Faculty of Health Science, Samsun, Turkey ${ }^{2}$ Department of Medical Nursing, İstanbul University-Cerrahpaşa Florence Nightingale Faculty of Nursing, İstanbul,Turkey ${ }^{3}$ Department of Neurology, İstanbul University İstanbul Faculty of Medicine, İstanbul, Turkey ${ }^{4}$ Department of Neurology, İstanbul University Cerrahpaşa Faculty of Medicine, İstanbul, Turkey ${ }^{5}$ Department of Oral and Maxillofacial Surgery, İstanbul University Faculty of Dentistry, İstanbul, Turkey ${ }^{6}$ Department of Neurosurgery, İstanbul University İstanbul Faculty of Medicine, İstanbul, Turkey ${ }^{7}$ Department of Public Health, İstanbul University İstanbul Faculty of Medicine, İstanbul, Turkey

\section{Summary}

Objectives: The aim of this study was to define knowledge and attitudes toward epilepsy among students of health occupations in a university. Methods: This descriptive study was conducted with a total of 544 university students from different health professions (medicine, nursing, dentistry, physiotherapy, and midwifery). To select the sample of the study, stratified sampling method was used. In this study, Epilepsy Attitude Scale and Epilepsy Knowledge Assessment Form were used.

Results: Among the 544 participants, 59.6\% were female and the mean age was 21.7 years. While the majority of the sample recognized a generalized tonic-clonic seizure, they did not know about other seizure types. The mean score of the Attitude Scale was 60.2 \pm 6.4 (range: 30-70). The attitudes were not different between males and females $(p=0.732)$. The students who had a family member with epilepsy $(p=0.004)$ or witnessed a seizure $(p=0.05)$ and attended upper classes had a more positive attitude $(p=0.004)$.

Conclusion: Although the sample of this study which consisted of students from health occupations had moderate to good attitude toward epilepsy; they still have a lack of knowledge in particular areas. Each faculty needs to re-arrange their curriculum to fill this knowledge gap.

Keywords: Attitude; epilepsy; health occupations; knowledge; student.

\section{Özet}

Amaç: Bu çalışmanın amacı bir üniversitede sağlık alanında eğitim gören öğrencilerin epilepsi hakkındaki bilgi, tutum ve davranışlarını değerlendirmektir.

Gereç ve Yöntem: Tanımlayıcı nitelikte olan bu çalışma bir üniversitenin farklı sağlık meslek gruplarında öğrenim (tıp, hemşirelik, diş hekimliği, fizyoterapi, ebelik) gören 544 öğrenci ile gerçekleştirildi. Örneklem seçiminde tabakalı örnekleme yöntemi kullanıldı. Çalışmada Epilepsi Tutum Ölçeği ve epilepsi bilgi formu kullanıldı.

Bulgular: Çalışmaya dahil edilen 544 öğrencinin $\% 59.6$ 'sı kadın ve yaş ortalaması 21.7 idi. Örneklemin büyük çoğunluğu jeneralize tonik klonik nöbetleri tanıyabilmesine rağmen diğer nöbet çeşitleri hakkında bilgilerinin yetersiz olduğu saptandı. Epilepsi Tutum Ölçeği ortalaması $60.2 \pm 6.4$ (range: $30-70$ ) olarak bulundu. Tutum puanının cinsiyete göre farklılaşmadığı saptandı $(p=0.732$ ). Ancak ailesinde epilepsi hastası olan $(p=0.004)$, nöbete tanık olan ( $p=0.05)$ ve üst sınıftaki öğrencilerin tutumlarının daha iyi olduğu belirlendi $(p=0.004)$.

Sonuç: Epilepsiye karşı tutumları orta-iyi düzeyde olduğu sapatanan sağlık öğrencilerinin hala bazı konularda yetersiz bilgiye sahip olduğu görüldü. Epilepsi konusundaki bilgi yetersizliğini gidermek için her fakültenin müfredat programını gözden geçirmesi gerekmektedir.

Anahtar sözcükler: Tutum; epilepsi; sağlık meslek; bilgi; öğrenci.

(C) 2019 Turkish Epilepsy Society
Submitted (Geliş): 02.07.2018

Accepted (Kabul) : 10.09.2018

Correspondence (iletişim): Zeliha TÜLEK, M.D.

e-mail (e-posta): tulekz@yahoo.com 


\section{Introduction}

Although epilepsy, which affects 50 million individuals worldwide, may be controlled through medical treatment, incorrect beliefs and insufficient knowledge on the disease increase the stigma level of the patients. ${ }^{[1]}$ Incorrect beliefs about the disease are not limited to the general population; it has been demonstrated that misinformation and negative attitudes are common among health providers as well. In Saudi Arabia, $10.5 \%$ of the health workers believe that epilepsy is related to supernatural events, $7.4 \%$ do not let children play with those with the disease, and $67.2 \%$ oppose the marriage of their family members with individuals with epilepsy. ${ }^{[2]}$ It has been reported in a study conducted in Georgia that $20 \%$ of health workers believe that epilepsy is a psychiatric disease, $82 \%$ oppose marriage of their family members with individuals that have epilepsy, and 13\% do not let their children play with children having this disease..$^{[3]}$ In Nigeria, the attitudes of health workers and the general population toward patients with epilepsy were evaluated, and no significant difference was observed between the groups; the study revealed similarly high rates of negative attitudes. ${ }^{[4]}$

The possibility of meeting patients with epilepsy is higher among health workers or candidates/students compared to other individuals of the population. Therefore, health workers' knowledge and attitudes toward patients with epilepsy would alter the extent of the professional care and the social support they provide. Naturally, sufficient knowledge and a positive attitude of health workers are extremely important to provide the best care for the patients, to avoid any tendency toward unproven methods that may harm their health, and to reduce stigma. ${ }^{[5-7]}$ With this point of view, studies should be conducted to evaluate the knowledge, attitude, and behavior of health workers or students in any field of health.

The literature search indicates that knowledge, attitude, and behaviors toward epilepsy have mostly been studied in teachers, patients and patients' relatives in the society. ${ }^{[8-18]}$ The number of studies about the knowledge and attitude of students of the health occupations is limited. ${ }^{[5,19-21]}$ The aim of this study was to evaluate the knowledge, attitude, and behavior of students involved in different fields of health toward epilepsy.

\section{Materials and Methods}

\section{Data collection}

This descriptive study was conducted on students of health-related faculties (medicine, nursing, dentistry, midwifery, and physiotherapy) of Istanbul University between February and June 2016. Among 3147 students that constituted the universe of the study, the study sample size was calculated using the stratified sampling method, and a total of 544 students were included in the study. Before the data collection, ethical approval was obtained from the ethical board of the university. The students were accessed during the lectures and the aim of the study was explained. Consents of the participating students were obtained.

\section{Data collection tools}

To measure the knowledge and awareness of the students regarding epilepsy, a question pool was formed through literature search, and the questionnaire was reviewed by an expert panel comprising an epilepsy neurologists, neurology nurses, and a public health specialist experienced in measurement and evaluation. The questionnaire was applied on 20 students for pilot testing. The first part of the questionnaire included the sociodemographic characteristics of the students; the second part included questions on their experience and awareness as well as their knowledge on medical issues, and the last part comprised questions on the knowledge of the social impacts of epilepsy. The students were asked to choose from options that were given in the survey form.

To determine the attitudes of the students toward epilepsy, the Epilepsy Attitude Scale developed by Aydemir was used. This 14-item-Likert type scale evaluates the attitude toward epilepsy. The scores obtained from the scale vary between 14 and 70, and high scores indicate positive attitudes. The validity and reliability of the scale were confirmed with a Cronbach's alpha value of $0.84 .^{[22]}$

\section{Data analysis}

The data analysis was carried out using the SPSS (version 21.0, IBM SPSS Inc, Armonk, NY) program. To define the tests to be used in the comparisons, the normality distribution was carried out using the Kolmogorov-Smirnov Test. Non-parametric tests were used since the data were not fit for the normal distribution. Descriptive statistics (mean standard deviation, range, numbers, and percentages), the Mann-Whitney U-test, and the Kruskal-Wallis test were used for analysis of the study data.

\section{Results}

The mean age was $21.7( \pm 1.57)$ years; $59.6 \%$ were female 
and $58.6 \%$ were students of the medical faculty. Approximately, half of the students had attended a course on neurology and epilepsy (48.3\%); however, the vast majority had no internship in the neurology clinics (73.2\%). The rate of students having a patient with epilepsy in the family/surrounding was $17.5 \%$, the rate of those who had encountered an epileptic seizure previously was $38.1 \%$ and the rate of those who had intervened a seizure was $<7.0 \%$. The rate of students who had felt competent for intervening a seizure was $21.9 \%$ (Table 1 ).

When the clinical features of various types of seizures were given, and the students were asked to recognize whether it was an epileptic seizure or not, a high rate of students recognized the tonic-clonic seizures (95.8\%), whereas a low rate recognized focal seizures (38.1\%). Some of the students had stated that epilepsy was related to being overfrightened in the past (38.6\%), depression (32.2\%), or psychosis (39.7\%). With regard to intervening the seizure, they reported making patients smell substances such as onion, garlic or cologne $(8.1 \%)$, drink water $(4.4 \%)$, and open the hands and arms of the patients (7.7\%). For the questions on factors that trigger epilepsy, many students answered this as situations such as stress (93.9\%), insomnia and fatigue (83.5\%), and irregular use of the drugs (96.7\%). A low rate of students suggested the menstrual cycle as a factor for trigger (42.3\%). The rate of students that believed epilepsy was a psychiatric problem was $7.7 \%$, whereas one-third of the students (34.2\%) believed that epilepsy impaired cognitive functions even when seizures were under control (Table 2).

The students were asked what the proper occupation for patients with epilepsy was and the vast majority answered the question as an accountant (91.7\%) and teacher $(82.7 \%)$; the rates of students who suggested medical secretary or family physician as the proper occupation were $48.3 \%$ and $49.4 \%$, respectively. Although motor car driving is forbidden for these patients in Turkey, the rate of those who reported that it was not a legal obstacle was $52.4 \%$ (Table 3).

The scores for the attitudes of the students toward epilepsy were observed to be nearly good (60.2 \pm 6.4 , range $30-70)$. The score obtained from the scale showed no difference between genders $(p=0.732)$. Significantly higher scores were observed among students having a patient with epilepsy
Table 1. Sociodemographic characteristics and experiences related to epilepsy of students

\begin{tabular}{|c|c|c|}
\hline Characteristics & $\mathrm{n}$ & $\%$ \\
\hline Age, Mean \pm SD (Range) & \multicolumn{2}{|c|}{$\begin{array}{c}21.7 \pm 1.57 \\
(19-31)\end{array}$} \\
\hline \multicolumn{3}{|l|}{ Gender } \\
\hline Male & 220 & 40.4 \\
\hline Female & 324 & 59.6 \\
\hline \multicolumn{3}{|l|}{ Faculty } \\
\hline Medicine & 321 & 58.6 \\
\hline Nursing & 85 & 15.6 \\
\hline Dentistry & 72 & 13.2 \\
\hline Midwifery & 31 & 5.7 \\
\hline Physiotherapy & 37 & 6.8 \\
\hline \multicolumn{3}{|l|}{ Class } \\
\hline $2^{\text {nd }}$ & 90 & 16.5 \\
\hline $3^{\text {rd }}$ & 191 & 35.1 \\
\hline $4^{\text {th }}$ & 63 & 11.6 \\
\hline $5^{\text {th }}$ & 200 & 36.8 \\
\hline \multicolumn{3}{|c|}{ Attending a course about epilepsy } \\
\hline Yes & 263 & 48.3 \\
\hline No & 281 & 51.7 \\
\hline \multicolumn{3}{|c|}{ Internship in the neurology clinic } \\
\hline Yes & 146 & 26.8 \\
\hline No & 398 & 73.2 \\
\hline \multicolumn{2}{|c|}{ Having patient with epilepsy } & in family/surrounding \\
\hline Yes & 95 & 17.5 \\
\hline No & 449 & 82.5 \\
\hline \multicolumn{3}{|l|}{ Witnessing a seizure } \\
\hline Yes & 207 & 38.1 \\
\hline No & 337 & 61.9 \\
\hline \multicolumn{3}{|c|}{ Experience of first aid for a seizure } \\
\hline Yes & 38 & 7.0 \\
\hline No & 506 & 93.0 \\
\hline \multicolumn{3}{|c|}{$\begin{array}{l}\text { Feeling self-competent in first } \\
\text { aid for seizure }\end{array}$} \\
\hline Yes & 119 & 21.9 \\
\hline No & 425 & 78.1 \\
\hline
\end{tabular}

SD: Standard deviation.

in the family/surrounding $(p=0.004)$ compared to the students without, and in students who had encountered an epileptic seizure previously ( $p=0.052$ ) compared to the ones who had not. Higher scores were obtained by students joining an educational activity (such as seminar and class) on epilepsy compared to those who did not $(p=0.009)$ and by students attending higher classes compared to those who did not $(p=0.004)$ (Table 4). 
Table 2. Students' knowledge of epilepsy

\begin{tabular}{|c|c|c|c|c|c|}
\hline Characteristics & $\mathrm{n}$ & $\%$ & Characteristics & $\mathrm{n}$ & $\%$ \\
\hline Able to recognize types of seizure & & & Which of the following are necessary & & \\
\hline Tonic-clonic seizures & 521 & 95.8 & for follow-up of a patient with & & \\
\hline Absence seizures & 288 & 52.9 & epilepsy? & & \\
\hline Myoclonic seizures & 303 & 55.7 & Blood levels of antiepileptics & & \\
\hline Atonic seizures & 354 & 65.1 & quarterly & 360 & 66.2 \\
\hline Focal seizures & 207 & 38.1 & Seizure diary & 432 & 79.4 \\
\hline Etiologic factors of epilepsy & & & Electroencephalography monthly & 298 & 54.8 \\
\hline Head trauma & 379 & 69.7 & Biochemistry twice a year & 314 & 57.7 \\
\hline Cranial tumors & 370 & 68.0 & Epilepsy is a mental health problem & & \\
\hline Cerebrovascular diseases & 309 & 56.8 & Yes & 42 & 7.7 \\
\hline Genetic & 422 & 77.6 & No & 502 & 92.3 \\
\hline Depression & 175 & 32.2 & Epilepsy is a contagious disease & & \\
\hline Very afraid of something & 210 & 38.6 & Yes & 4 & 0.7 \\
\hline Psychosis & 216 & 39.7 & No & 540 & 99.3 \\
\hline Factors that trigger seizures & & & Epilepsy can be controlled with & & \\
\hline Stress & 511 & 93.9 & treatment & & \\
\hline Insomnia and fatigue & 454 & 83.5 & Yes & 502 & 92.3 \\
\hline Menstrual period & 230 & 42.3 & No & 42 & 7.7 \\
\hline Irregular use of drugs & 526 & 96.7 & Epilepsy patients (except at the & & \\
\hline $\begin{array}{l}\text { Use of any additional medication } \\
\text { (antibiotics, etc.) }\end{array}$ & 359 & 66.0 & $\begin{array}{l}\text { moment of seizures) are responsible } \\
\text { for the crimes they committed }\end{array}$ & & \\
\hline What can be done for seizure first aid? & & & Yes & 366 & 67.3 \\
\hline Preventing head trauma & 474 & 87.1 & No & 178 & 32.7 \\
\hline Checking the consciousness & 529 & 97.2 & Epilepsy, impairs cognitive function, & & \\
\hline Turning head to one side & 446 & 82.0 & even if it is under controlled & & \\
\hline Trying to open jaw & 248 & 45.6 & Yes & 186 & 34.2 \\
\hline Elevating the foot & 165 & 30.3 & No & 358 & 65.8 \\
\hline $\begin{array}{l}\text { Having patient sniff onions, } \\
\text { garlic, cologne, etc }\end{array}$ & 44 & 8.1 & $\begin{array}{l}\text { Epilepsy treatment should be interrupted } \\
\text { during pregnancy until birth }\end{array}$ & & \\
\hline Having patient drink water & 24 & 4.4 & Yes & 155 & 28.5 \\
\hline Trying to open the arm & 42 & 7.7 & No & 389 & 71.5 \\
\hline
\end{tabular}

\section{Discussion}

The aim of this study conducted on students of different fields of health was to investigate their knowledge, attitude, and behavior toward epilepsy. Among these, 38.1\% reported that they had encountered a seizure and only $7 \%$ had intervened the seizure. Witnessing an epileptic seizure may affect the attitude and behavior toward this disease. $21.9 \%$ of the students had reported that they felt competent to intervene a seizure; hence, a low rate of intervention is an expected situation. However, considering the fact that half of the students had attended courses on epilepsy and one-fourth of them had gone through an internship in the neurology clinics, it is a matter of concern that they did not feel competent to intervene a seizure. It was reported in a study investigating the knowledge and attitudes of nursing students in Turkey that $43 \%$ had felt incompetency and 35\% had felt fear when witnessing an epileptic seizure, although $62.5 \%$ had attended courses on the subject. ${ }^{[2]}$ With this point of view, it is important to reconsider the content and duration of education on epilepsy in the curriculum.

The students were asked to define different types of seizures; almost all (95.8\%) could recognize tonic-clonic seizures, however, the rate of recognizing focal seizures was really low (38.1\%). In different studies, students have defined epilepsy as generalized tonic-clonic convulsions and loss of consciousness. ${ }^{[3,5,20]}$ In this respect, it was concluded that the students had insufficient knowledge of the types of seizures, which should be improved. 
Table 3. Students' knowledge of the impact of epilepsy on social life

\begin{tabular}{|c|c|c|c|c|c|}
\hline Characteristics & $\mathrm{n}$ & $\%$ & Characteristics & $\mathrm{n}$ & $\%$ \\
\hline $\begin{array}{l}\text { What kind of sport is suitable for } \\
\text { patients with epilepsy? }\end{array}$ & & & $\begin{array}{l}\text { Patient with epilepsy can be } \\
\text { successful in school life }\end{array}$ & & \\
\hline Walking & 525 & 96.5 & Yes & 536 & 98.5 \\
\hline Yoga & 529 & 97.2 & No & 8 & 1.5 \\
\hline Climbing & 123 & 22.6 & Patient with epilepsy can live alone & & \\
\hline Diving & 30 & 5.5 & if their seizures are under controlled & & \\
\hline Parachute jump & 36 & 6.6 & Yes & 418 & 76.8 \\
\hline Which professions would be appropriate & & & No & 126 & 23.2 \\
\hline for patients with epilepsy? & & & In our country, there is no legal & & \\
\hline Teacher & 450 & 82.7 & obstacle for the use of motor vehicles & & \\
\hline Accountant & 499 & 91.7 & by a patient with epilepsy & & \\
\hline Medical secretary & 263 & 48.3 & Yes & 285 & 52.4 \\
\hline Family physician & 269 & 49.4 & No & 259 & 47.6 \\
\hline The crane operator & 71 & 13.1 & Which of the following disease & & \\
\hline Surgeon & 58 & 10.7 & would you prefer to have if you & & \\
\hline Nightwatchman & 171 & 31.4 & have to choose one? & & \\
\hline Carpenter & 142 & 26.1 & Epilepsy & 108 & 19.9 \\
\hline Electrical technician & 112 & 20.6 & Diabetes mellitus & 259 & 49.0 \\
\hline Children with epilepsy should go to the & & & Major depression & 117 & 22.1 \\
\hline school providing special education & & & Chronic respiratory problems & 22 & 4.2 \\
\hline Yes & 94 & 17.3 & Chronic cardiac problems & 23 & 4.3 \\
\hline No & 450 & 82.7 & Other (specify): None & 15 & 2.8 \\
\hline
\end{tabular}

Table 4. Epilepsy attitude scale and associated factors

\begin{tabular}{lcc}
\hline Factors & Mean $\pm S D$ & $Z / x^{2}, p$ \\
\hline $\begin{array}{l}\text { Epilepsy attitude scale score } \\
\text { Gender }\end{array}$ & $60.2 \pm 6.4$ & $30-70$ \\
$\quad$ Female & $60.4 \pm 6.07$ & $\mathrm{Z}=-0.343$ \\
$\quad$ Male & $60.0 \pm 6.86$ & $\mathrm{p}=0.732$ \\
$\begin{array}{l}\text { Having patient with epilepsy } \\
\text { in family/surrounding }\end{array}$ & & \\
$\quad$ Yes & $61.8 \pm 5.98$ & $\mathrm{Z}=-2.890$ \\
$\quad$ No & $59.9 \pm 6.44$ & $\mathrm{p}=0.004$ \\
Witnessing the epileptic & & \\
seizure & & \\
$\quad$ Yes & $60.9 \pm 6.05$ & $\mathrm{Z}=-1.944$ \\
$\quad$ No & $59.8 \pm 6.57$ & $\mathrm{p}=0.052$ \\
Attending a course about & & \\
epilepsy & & \\
$\quad$ Yes & $61.0 \pm 6.06$ & $\mathrm{Z}=2.597$ \\
$\quad$ No & $59.5 \pm 6.63$ & $\mathrm{p}=0.009$ \\
Class & & \\
$\quad 2^{\text {nd }}$ & $58.0 \pm 7.24$ & $\mathrm{X}^{2}=13.110$ \\
$3^{\text {rd }}$ & $60.2 \pm 6.22$ & $\mathrm{p}=0.004$ \\
$4^{\text {th }}$ & $60.6 \pm 5.37$ & \\
$5^{\text {th }}$ & $61.1 \pm 6.27$ & \\
\hline
\end{tabular}

In the Turkish society, different beliefs (e.g., being overfrightened in the past is believed to trigger the disease) and folk practices (making the patient smell onion or garlic during the seizure) may be observed on epilepsy and first aid of seizures. In our study, we observed that these wrong beliefs and behaviors were not limited to the general society only and that the students of health were also involved. In particular, making the patient smell odors to stop the seizure was observed to be continued by health-care-givers as well, although at a low rate (5\%), as reported in the study of Yaşar et al. ${ }^{[23]}$ Wrong beliefs and behaviors toward the disease are not limited to these, and efforts are being made to open the jaw of the patient or to stop involuntary contractions. In this study, $45.6 \%$ of the students had mentioned that they found the effort to open the jaw correctly. It has been observed in different studies conducted on students of medical fields that incorrect practices in intervening the seizures still exist. ${ }^{[19-21,24]}$ It may be concluded that not only students but also the health-care personnel and all individuals of the society should be informed about the subject.

In a recent study, the attitudes of students that are wellinformed about the causes and treatment of epilepsy 
were found to be more favorable. ${ }^{[5]}$ In this respect, a small percentage of students in our study had (7.7\%) defined epilepsy as a psychological disorder, and a very small percentage $(0.7 \%)$ defined it as an infectious disease, whereas almost all (92.3\%) had reported that epilepsy was a treatable disease. Although it is pleasing that epilepsy was not defined as a psychiatric or infectious disease in our study, studies have demonstrated that many students or workers of the medical field believe that it is so. ${ }^{[2,5,19]}$

Students were asked about the factors that trigger epileptic seizures and many of them answered the questions as situations such as stress, insomnia, fatigue, and irregular use of drugs. Small number of students suggested the menstrual cycle as a triggering factor. Due to hormonal change, the menstrual period has been reported as a seizure triggering factor among women, which has been expressed as catamenial epilepsy in the literature; ${ }^{[25]}$ however, students' knowledge about this subject is limited. Students who will be involved in the treatment and care of patients with epilepsy in the future should be carefully informed about the topic.

In addition to the medical knowledge of the students, the questions on the impact of epilepsy on social life were asked. Many of the students believed that being a teacher (82.7\%) or accountant $(91.7 \%)$ was appropriate for patients with epilepsy, whereas they disagreed on being a medical secretary $(48.3 \%)$ or a family physician $(49.4 \%)$. Another study on college students have reported that students have positive attitudes toward epilepsy in general but when the issue is work-life attitudes changed to negative. ${ }^{[26]}$ Authors concluded that this finding might be resulted from students' concerns regarding safety issues rather than an intention to discriminate patients.

About $17 \%$ of the students stated that patients with epilepsy should be educated in special training schools. Although it has been reported that factors such as frequent seizures, medications, and comorbidity affect the academic life of the individuals, ${ }^{[27,28]}$ this does not necessarily mean they would be unsuccessful in their academic lives and that they should be specially trained. These kinds of incorrect beliefs would affect the attitudes toward the patients as well. Therefore, informing students on the subject are crucial. Likewise, although it is forbidden for patients with epilepsy to drive in Turkey, ${ }^{[2]]}$ it was observed that almost half of the students (52.4\%) were not aware of this and that they had insufficient knowledge on the medical as well as social aspects of epilepsy.

Insufficient information, wrong beliefs, and attitudes on epilepsy bring along prejudgments. For example, in a study evaluating the stigma toward different chronic diseases such as epilepsy and diabetes, prejudgment toward epilepsy was reported to be higher compared to diabetes, and this was related to incorrect beliefs. ${ }^{[30]}$ In our study, the students were asked: "Which disease would you prefer if you were going to have one in the future?" They preferred diabetes to epilepsy, which is similar to the results of the study above.

In this study evaluating the attitude in addition to the knowledge and awareness on epilepsy, the attitudes of students toward epilepsy were different compared to public or patients with epilepsy (when compared to data of study by Aydemir et al..). ${ }^{[3]}$ It is noticeable that even after a decade; the younger and more educated population can have similar attitudes. Results show how difficult attitudes can change, especially toward stigmatizing diseases. It was observed that students who had encountered an epileptic seizure previously or those who had an epilepsy patient in the family or relatives had better attitudes. In another study conducted on students of the medical fields, it was observed that the attitudes of students who had encountered epilepsy cases previously were more favorable. ${ }^{[5]}$ It was also observed that students who had attended lectures on epilepsy in their curriculum programs had better attitudes. A higher level of knowledge and experience about patients with epilepsy, face-to-face observation of patients in clinical internships and thereby being familiar with the patients positively affect the attitudes of students.

\section{Conclusion}

The attitudes of students being educated in different fields of health sciences toward epilepsy were comparable with the general population and students still had insufficiencies in some of the issues. When it is considered that this insufficient information and wrong beliefs affect the attitudes towards the patients, it is important to emphasize that curriculum programs should be revised, and all individuals of the society, not only students of the medical fields, should be informed on epilepsy using the mass media. 


\section{Ethics Committee Approval}

Ethics committee approved.

\section{Peer-review}

Externally peer-reviewed.

\section{Conflict of interest}

The authors declare that they have no conflict of interest.

\section{Authorship Contributions}

Concept: Z.T., K.Y.; Design: Z.T., K.Y., N.B., E.Ö.; Supervision: N.B., B.B., C.G., A.G., N.Y.; Data collection \&/or processing: K.Y., A.Ç., H.G., N.Ş., A.Y., M.K.; Analysis and/or interpretation: Z.T., K.Y., EÖ; Literature search: K.Y., Z.T., A.Ç.; Writing: K.Y., Z.T., N.B., B.B., C.G.; Critical review: A.G., G.A., N.B.

\section{References}

1. Bandstra NF, Camfield CS, Camfield PR. Stigma of epilepsy. Can J Neurol Sci 2008;35(4):436-40. [CrossRef]

2. Alaqeel A, Alebdi F, Sabbagh AJ. Epilepsy: What do health-care professionals in Riyadh know? Epilepsy Behav 2013;29(1):2347. [CrossRef]

3. Gzirishvili N, Kasradze S, Lomidze G, Okujava N, Toidze O, de Boer HM, et al. Knowledge, attitudes, and stigma towards epilepsy in different walks of life: A study in Georgia. Epilepsy Behav 2013;27(2):315-8. [CrossRef]

4. Ekenze OS, Ndukuba AC. Perception of epilepsy among public workers: Perspectives from a developing country. Epilepsy Behav 2013;26(1):87-90. [CrossRef]

5. Njamnshi AK, Tabah EN, Bissek AC, Yepnjio FN, Angwafor SA, Dema $F$, et al. Knowledge, attitudes and practices with respect to epilepsy among student nurses and laboratory assistants in the South West region of Cameroon. Epilepsy Behav 2010;17(3):381-8. [CrossRef]

6. Chomba EN, Haworth A, Atadzhanov M, Mbewe E, Birbeck GL. Zambian health care workers'knowledge, attitudes, beliefs, and practices regarding epilepsy. Epilepsy Behav 2007;10(1):111-9.

7. Harimanana A, Chivorakul P, Souvong V, Preux PM, Barennes H. Is insufficient knowledge of epilepsy the reason for low levels of healthcare in the Lao PDR? BMC Health Serv Res 2013;13(1):41.

8. Ullah S, Nabi G. Knowledge, attitude and practices of school teachers towards epileptic school students at district Dir lower, Khyber Pakhtunkhwa, Pakistan. Int J Neurosci Behav Sci 2015;3(1):1-6.

9. Ryu HU, Lee SA, Eom S, Kim HD, Korean QoL in Epilepsy Study Group. Perceived stigma in Korean adolescents with epilepsy: Effects of knowledge about epilepsy and maternal perception of stigma. Seizure 2015;24:38-43. [CrossRef]

10. Ezeala-Adikaibe BA, Achor JU, Nwabueze AC, Agomoh AO, Chikani M, Ekenze OS, et al. Knowledge, attitude and practice of epilepsy among community residents in Enugu, South East Nigeria. Seizure 2014;23(10):882-8. [CrossRef]

11. Abulhamail AS, Al-Sulami FE, Alnouri MA, Mahrous NM, Joharji DG, Albogami MM, et al. Primary school teacher's knowl- edge and attitudes toward children with epilepsy. Seizure 2014;23(4):280-3. [CrossRef]

12. Bishop M, Boag EM. Teachers' knowledge about epilepsy and attitudes toward students with epilepsy: Results of a national survey. Epilepsy Behav 2006;8(2):397-405. [CrossRef]

13. Shehata GA, Mahran DG. Knowledge, attitude and practice with respect to epilepsy among school teachers in Assiut city, Egypt. Epilepsy Res 2010;92(2):191-200. [CrossRef]

14. Teferi J, Shewangizaw Z. Assessment of knowledge, attitude, and practice related to epilepsy: A community-based study. Neuropsychiatr Dis Treat 2015;11:1239-46.

15. Bekiroğlu N, Ozkan R, Gürses C, Arpaci B, Dervent A. A study on awareness and attitude of teachers on epilepsy in Istanbul. Seizure 2004;13(7):517-22. [CrossRef]

16. Üçer H, Sucaklı MH, Çelik M, Keten HS. Primary school teachers' knowledge, attitudes and behaviors about childhood epilepsy. Cukurova Med J 2016;41(3):491-7. [CrossRef]

17. Sivri BB, Öpulat F. İlköğretimde görevli öğretmenlerin epilepsiye ilişkin bilgi, tutum ve davranışları (Knowledge, attitudes and behaviors of the teachers teaching at primary schools about epilepsy). Epilepsi 2013;19(2):71-8. [CrossRef]

18. Yang RR, Wang WZ, Snape D, Chen G, Zhang L, Wu JZ, et al. Stigma of people with epilepsy in China: Views of health professionals, teachers, employers, and community leaders. Epilepsy Behav 2011;21(3):261-6. [CrossRef]

19. Falavigna A, Teles AR, Roxo MR, Velho MC, Silva RC, Mazzocchin $T$, et al. Awareness and attitudes on epilepsy among undergraduate health care students in Southern Brazil. J Epilepsy Clin Neurophysiol 2009;15(1):19-23. [CrossRef]

20. Özdemir Ö. Öğrenci Hemşirelerin Epilepsiye Ilişkin Bilgi ve Tutumlarının Değerlendirmesi (Evaluation of Knowledge and Attitudes of Student Nurses Regarding Epilepsy). İstanbul Bilim Üniversitesi Sağlık Bilimleri Enstitüsü Yüksek Lisans Tezi, (Istanbul Bilim University Institute of Health Sciences Master's Thesis); 2012.

21. Göktaş SB, Yıldız T, Köse S. First aid knowledge of nursing students in epileptic cases. Int J Basic Clin Med 2015;3(2).

22. Aydemir N. Developing two different measures for assessing knowledge of and attitudes toward epilepsy for the Turkish population. Epilepsy Behav 2008;12(1):84-9. [CrossRef]

23. Yaşar $H$, Tekeli $H$, Balıbey $H$, Alay, S. Epilepsi hastaları ve sağlık personelinin epilepsi hastalığı hakkında bilgi ve tutumlarının değerlendirilmesi (Assesment of knowledge and attidudes of patients with epilepsy and health professionals about epilepsy disease). Epilepsi 2013;19(3):127-31. [CrossRef]

24. Tedrus GM, Fonseca LC, Vieira AL. Knowledge and attitudes toward epilepsy amongst students in the health area: Intervention aimed at enlightenment. Arq Neuropsiquiatr 2007;65(4B):1181-5. [CrossRef]

25. Verrotti A, D'Egidio C, Agostinelli S, Verrotti C, Pavone P. Diagnosis and management of catamenial seizures: A review. Int J Womens Health 2012;4:535-41. [CrossRef]

26. Young GB, Derry P, Hutchinson I, John V, Matijevic S, Parrent L, 
et al. An epilepsy questionnaire study of knowledge and attitudes in Canadian college students. Epilepsia 2002;43(6):6528. [CrossRef]

27. Jones JE, Siddarth P, Gurbani S, Shields WD, Caplan R. Cognition, academic achievement, language, and psychopathology in pediatric chronic epilepsy: Short-term outcomes. Epilepsy Behav 2010;18(3):211-7. [CrossRef]

28. van Rijckevorsel K. Cognitive problems related to epilepsy syndromes, especially malignant epilepsies. Seizure 2006;15(4):227-34. [CrossRef
29. Topçuoğlu OB. Türkiye'de epilepsi ve araç kullanimi (epilepsy in Turkey and driving). New Symp 2011;49(4):237-9.

30. Fernandes PT, Salgado PC, Noronha AL, Barbosa FD, Souza EA, Sander JW, et al. Prejudice towards chronic diseases: Comparison among epilepsy, AIDS and diabetes. Seizure 2007;16(4):320-3. [CrossRef]

31. Aydemir N, Ünsal P, Özkara Ç. Epilepsisi olan bireylerin epilepsiye dair sahip oldukları tutum, bilgi ve bilgi kaynakları. (Level of knowledge about and attitude toward and sources of information about epilepsy) Epilepsi 2011;17(3):90-6. [CrossRef] 